\title{
統合医療の科学技術戦略
}

\author{
田邊 敏憲
}

株式会社富士通総研経済研究所主席研究員

\section{The Realization of Japanese Integrated Medical Care through the Science and Technology Strategy}

\author{
Toshinori TANABE
}

SENIOR fellow, Economic Research Center, Fujitsu Research Institute

\begin{abstract}
Based on the effectiveness and quantification ("making visible") of traditional medicine and food made possible by the spread of IT (information technology) which began in the US and elsewhere in the $90 \mathrm{~s}$, the coding of (about 7,000 kinds) and database creation for traditional Chinese medical herbs has been advanced and the acquisition of patents in the field of traditional medicine has become active.

Intellectual property and patent strategies greatly affect the science and technology policy of each country, as symbolized by the pro-patent stance of the US with regards to traditional medicine. It is time that Japan follows this major global trend and makes nationwide efforts towards the realization of integrated medical care.

The first thing Japan must do is integrate its medical policy and science and technology policy, as well as integrate the kind of "compartmentalized and narrow" policy of its various ministries (the Ministry of Health, Labor and Welfare, the Ministry of Agriculture, Forestry and Fisheries, the Ministry of Education, Culture, Sports, Science and Technology, and the Ministry and Economy, Trade and Industry).

Japan has a tendency to have brain freeze from being "policy-dependent", but from the perspective of it being a central player, it is also has a more conducive environment for establishing integrated medical care compared to China or South Korea. In other words, because the parallel existence of western medicine and eastern medicine has been a national policy in China and South Korea, the two practices are in fierce conflict like "water and oil" and as such integration would be highly difficult. Fortunately in Japan, however, western medical doctors are reorganizing eastern medicine as medicine that is based on scientific and objective data (Evidence Based Medicine), and are endeavoring towards a fusion of the two.

In addition, Japan is beginning to establish the farming and fisheries industry, which has traditionally existed in every region, as an industry that promotes safety and strengthens immune systems. It is a transition from a "foods industry" to a "health industry". In every region there is the expectation that "medical, food, agricultural and environmental" industries will be integrated, and that environments where future generations can lead reassured lifestyles in these regions will be created. Japan is becoming an aging society ahead of the rest of the world, its population is in rapid decline, and the creation of employment opportunities (industry) is being demanded. The making of eastern medicine, in which food is a critical element, into a science ; in other words, the "science and technology strategy of integrated medical care", will contribute to regional revitalization.
\end{abstract}

Key words : IT \& the science and technology strategy realize japanese IM system

\section{要旨}

米国などでは1990年代央から普及が始まったIT（情報通信技術）で可能となった伝統医療・食品の有効性やその 定量化（“見える化”）を踏まえ，漢方薬草のコード化（約7,000種類）・DB 化を進め, 伝統医療分野での特許取得 も活発となっている。

米国の伝統医療に対するプロパテント姿勢に象徵されるように，知財・特許戦略など各国の科学技術政策にも大 きく影響するだけに，世界の大きな潮流に沿って，今こそ日本も，統合医療実現のための国をあげての取組みが必 要である。

日本がまずなすべきことは，医療政策と科学技術政策の統合，厚生労働省・農水産省・文部科学省・経済産業省 政策の統合など，各省の“縦割り蛸壼”型政策の統合である。 
“政策頼み”で思考停止となってしまいがちの日本であるが, 肝心のプレーヤーという視点で考えると, 中国, 韓国と比べても，日本の方が統合医療を確立しやすい環境にある。すなわち，中韓では，西洋医学と東洋医学の並 存を国是としてきたため, 両者間には“水と油”のような激しい対立があり，その統合はきわめて難しいとされる。 しかし幸いにも日本では，西洋医学医師が科学的な，すなわち客観的データに基づく医療（EBM<Evidence Based Medicine））として東洋医学を再構成し，両者の融合に努めている。

加えて日本でも, 従来から各地域に存在する農水産業を安全·安心かつ免疫力を高める産業として捉え始めてい る。農水産業の「食料産業」から「健康産業」化である。どの地域においても, “医·食·農・環”産業が統合され， 子々孫々の代までもその地での生活が見通せる場作りが求められている。食が極めて重要な要素を占める東洋医学 の科学化, すなわち「統合医療の科学技術戦略」は, 世界に先駆けて少子高齢化社会に突入, 過疎化が急速に進み, 雇用の場 (産業) の創出を求めている日本の各地域再生にも貢献することになる。

キーワード：IT，科学技術戦略による統合医療実現

石川 おはようございます。朝の一番からお集ま りいただきまして, 誠にありがとうございます。「統 合医療の科学技術戦略」という演題で, 田邊先生に ご講演いただくことになっております。

恒例ですので，ご略歴をご紹介させていただきま す。先生は，1949年に広島県の庄原市でお生まれに なり，1973年に京都大学法学部を卒業され，1973年 に日銀に入行されて大蔵省へ出向され, 日銀の二 ユーヨーク駐在員, 日銀考査局, 日銀調査統計局, 日銀長崎支店長などを歴任され，1997年に退職され て, その後, 1998年に富士通総研経済研究所主席研 究員となられました。2004年に東京大学大学院の非 常勤講師としてシステムイノベーション論を担当さ れ，2005年から京都大学大学院エネルギー科学研究 科客員教授を 2 年間なされ，2006年からは埼玉大学 大学院経済科学研究科客員教授をされています。

わたしは先生を日経新聞の論文を拝見させていた だきましたが，相当総合的な考え方をお持ちの方だ と拝察致しております。まさに今の世の中は経済が 主流になっているのですが，医学，特に医療をやっ ていると意外に経済音痴で，どう考えていいのかよ く分からないところもあります。そういった意味で は, 今日の先生のご講演でいろいろな意味で勉強さ せていただけるのではないかと期待しております。 先生よろしくお願いいたします。
田邊 ご紹介いただきました田邊でございます。 今, 石川先生にざっとわたしの経歴をご紹介いただ きましたように，わたしは日本銀行で24年半，経済， 金融について訓練を受けてまいりまして，10年前か ら, 親会社がシステム会社の富士通で, そこの子会 社である富士通総研というところで，いわゆるシン クタンクの研究者として研究しております。

わたしのテーマは何かというと, 今いろいろな分 野で大きな話題となっていますが，少子高齢化と いった日本の社会になった場合，日本人は一体どう いった形で飯を食っていく産業を作っていったらい いのか, こういう視点で戦略を練る研究をしていま す。そういう過程で, 中国経済の課題は何か, アメ リカ経済の将来性と課題は何なのかなど，いろいろ と考えていますが，つくづく医療の世界は象徵的な 産業分野になると感じているわけです。

こういう視点で，アメリカの産業も調べています。 アメリカで最も大きな産業は何か皆さんご存じです か。結論的に申しますと, 医療業界, ヘルスケア産 業です。ちょっと数字を言って恐縮です。アメリカ の GDP は大体13兆ドルで, そのうち約 $1 / 6$ が医療 産業です。それだけ大きな産業になっています。し かも，アメリカは一時期日本の競争力に破れてもう 䭾目になるかと思いましたが，1990年代以降見事に 復活しています。何で復活したのか。一つは, IT 革命などで産業構造を全く変えたわけです。そのと きにどの分野で仕事が増えたかというとサービス産 業なのですが，何のサービスかというとへルスケア 産業のサービスなのです。そこでみんな何をやって いるのかいろいろ調べてみますと，今日の話のテー マになります。

われわれ日本人が昔から漢方と言って親しんでき 
た伝統医療について，コンピューター，インターネ ットなど IT 革命の総力を尽くして特許をどんどん 取っています。

皆さん特許と言ったら，何を思われますか。特許 が成立するためには，例えば，漢方の薬草でも，A という漢方の薬草と B という漢方の薬草は明らか に違うというコード化が前提になります。コードで す。それでアメリカがやったことは何かというと， チベット医学では, 薬草がすごく大きな役割を占め ているのですが，7000種類あるということで，よそ さまの国の漢方薬草のコード化を完成させました。 7000種類あるわけです。そのコード化ができますと， あとはIT の世界ですから，枝葉で分かれていって， $\mathrm{A}$ という薬草の下にある特許と, $\mathrm{C}$ という薬草の特 許は全然違うものです。どこが違うのか，どこが同 じなのかということで，いわゆるシステム特許をど んどん押さえられることになる。われわれが知らな いうちにアメリカがやっているわけです。そしてあ る日突然，日本ではキンギンソウといって，おふく ろが裏山で採ってきて「熱冷ましになる」と言って いたものが，アメリカがその特許を押さえた上で新 しい薬品として日本などを制覇する，そういう時代 が目と鼻の先に来ているわけです。

なぜこんなにアメリカと日本は違うのか。そうい う問題意識がそもそもわたしのように経済や産業を やっている人間にはありまして，その立場から，歯 がゆい思いで科学技術戦略の差ということで世の中 に問題提起したわけです。それが先ほど石川先生に お話しいただいた，昨年 4 月27日付け日経の経済教 室の論文でした。

ちなみに，そこで言ったことがもう一つあります。 アメリカは, ヘルスケア産業で最大の雇用を生んで います。患者が扔医者さんに診てもらうと，日本の お医者さんはカルテを書く段階では，大体は自分で 全部書かれます。アメリカは違います。お医者さん が診断したら，その診断をボイスでまず伝える。そ のボイスでもって，アシスタントが，どんどん電子 カルテに入力していくわけです。分業ができていま す。そういう形でIT, コンピューター，インター ネットを使って，医療の世界を分業した上で統合す る体制ができています。

もう一つ大きな変化があります。これは僕の専門 の世界ですが，皆さんご存じのように，新聞を見ま
すとアメリカは経常収支や貿易収支の大幅赤字だ， 財政の大幅赤字た，いずれこうなってしまうとドル は大暴落するはずだという議論をしています。しか し, 今, アメリカはモノの輸出入や貿易収支では大 幅赤字ですが，新しい輸出産業を生み出しました。 それは何か。医療なのです。

今，世界で最もにぎわっている所はどこでしょう か。ドバイなど中近東の産油国，いろいろな王室が ある所です。こういう所に金が，オイルマネーがわ んさか余っています。ドバイに行った方はご存じで しょうが，今，世界の高層ビルを建設するクレーン の 2 割以上が集中しています。もうバベルの塔みた いな状況になっているわけです。そこでみんな何を 最も欲しがっているか。9.11を契機に，イスラムの 人はアメリカに行きにくくなりました。その結果, 先端医療を受けられなくなったわけです。そして， どういうことが今起こっているかというと，特にこ ういう中近東の王室系統の人は近親結婚が多いそう で，糖尿病などはある意味でビルトインされた疾病 になっているそうです。そこで彼等が求めるのはア メリカの先端医療で，アメリカの先端医療を使いた いというニーズがあるわけです。

しかしながら，9.11によってイスラムの人たちは アメリカから遮断されて, 何が始まったか。ハー バード大学やワシントン大学のドバイなどへの進出 が始まりました。今, 二つの大学が, 中近東に大学 病院ごと輸出しています。そして, 中近東のハーバー ド大学にしろ，ワシントン大学にしろ，そこでしっ かり勉強を修了した人は，アメリカの医師免許が取 れます。難しいことがあれば，画像処理をして本国 のハーバード大学やワシントン大学の医療センター で診断します。こういう事態が発生しているわけで す。

従って，アメリカの戦略は，一方では東洋医学で, 例えば漢方であり, チベット医学であり, アーユル ヴェーダであり，そういったもののエッセンスをす べて ITによって特許で押さえてしまうという戦略 を発動する。他方で，医療サービスを輸出する。今 後は，あらゆる人にとっての最大のニーズは健康で あること，病気になりたくないことですから，そう いうサービスを輸出産業にしている。そして，これ はネットを通じてどんどん対価がアメリカに支払わ れてきますから，目には見えませんがこれでモノで 
の赤字をかなり補ってしまう構造になっています。 そういうことを考えていくうちに，わたしは日本 の産業戦略の専門家として，だんだん日本に何が足 りないのかと考えるようになりました。考えた結果， 大きく二つ足りないと考えています。安倍内閣に なって現在，イノベーションという言葉がとかく皆 さんの耳に入ってくると思います。イノベーション， 「技術革新」です。医療の世界でもイノベーション はあります。では，なぜイノベーションなのかとい うと, 経済が伸びていくには三つの要素が要ります。 一つは人口が増えること，すなわち労働力が増える こと。二つ目は設備投資をすること。三つ目はあら ゆる努力でイノベーションを起こし，一人当たりで 生み出す価值を高めること。この三つが必要なわけ です。

ところが，人口が減りますから，今後この点で日 本の経済が伸びることはない。設備投資がある程度 出ても，労働力の減り具合を何とか補うだけである。 では, 残されるのは何か。一人当たりの生み出す付 加価值をどうやって高めるか，すなわちイノベーシ ヨンということになるわけです。

ところで皆さんは, イノベーションというのは誰 が言った言葉かご存じですか。シュンペーターとい う人です。シュンペーターはちょうど100年前，ケ インズと同じ時期に出てきた人です。その人は, 100 年前はケインズほどには有名とはならなかった。な ぜかというと，ケインズは大不況のときに，政府が 仕事を作ってやれば経済は立ち直るのではないかと いう作戦を立てて，それがある程度成功したわけで す。しかし，そのやり方を戦後もやった結果，財政 赤字は増えるばかりで，経済の基本的な構造は全然 良くならないということになって，再びシュンペー ターが見直されているわけです。シュンペーターは, それぞれのプレーヤー，企業家，そして先生方のよ うなそれぞれの分野の研究者あるいは専門家，こう いった方々がどんどん工夫していって付加価值を付 けることが結局経済成長を生む，生産性を高めると 言った人なのです。

わたしは彼がすごく素晴らしいと思って，感心し ていることがあります。何を言ったのか。イノベー ションには五つあると言ったのです。

日本人というのは，イノベーションは技術革新だ から理系の人にしかできないと思いがちです。理系
・文系という区分けも日本特有だと思っているので すが，一応日本なりの分類でいきますと，わたしは 文系です。「じゃあ田邊はイノベーションできるの か」と言われますと，ふっと詰まります。「技術革 新だろう」と言われたら, 理工系の研究，分析，ア イデアがないと，やはり無理なのではないかとなる わけです。しかし，シュンペーターはそうは言って いないのです。

イノベーションには五つある。1 番目はプロダク トイノベーションです。半導体を発明する，内視鏡 を発明する，これは新製品を生み出すイノベーショ ンです。2 番目はプロセスイノベーションです。現 在，省エネや省資源が叫ばれていますが，モノづく りで日本は何が得意芸かと言うと，非常に工夫して 極力エネルギーを使わないようにする。そして，少 量多品種のモノでもいとも簡単に，短納期で，一人 で全て組み立てる屋台方式等で作ってしまう。これ はプロセスイノベーションで，日本人はこれが得意 です。3 番目はマテリアルイノベーションです。飛 行機は今, 炭素繊維の時代に入っています。東レが 開発した軽い素材です。こういったナノテクのよう な素材を開発するというのがマテリアルイノベーシ ヨンです。ここまでは，分かります。でも，これも 理科系がやることだろう。先生方も理科系だから, そう思われるかもしれません。しかし，それから先 にすごいことを言っています。４番目はマーケット イノベーション (市場革命)，5番目はシステムイ ノベーションです。「仕組み」を作るということで す。

そこで，わたしは医療も含めて，アメリカと日本 の強み・弱みを比較しました。なぜアメリカはあん なに強いのか。例えば，シリコンバレーで働いてい る人たちにアメリカ人はあまり多くありません。日 本人, 韓国人, 中国人，インド人，そういった理工 系の技術の教育・研修をしっかり受けた人材は，む しろアジアに多いわけです。彼らを集めて，シリコ ンバレーというトータルでいろいろな産業が生きる ようなシステムを作って，すなわち統合に成功した わけです。そういう地域の産業統合政策に成功した わけです。

アメリカ人が得意なのは何かというと, $1,2,3$ はそんなに強くありません。よそから連れてきた科

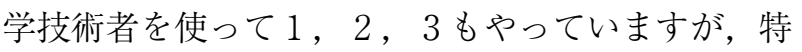


にすごいのは市場を作ることで，先ほどの医療の輸 出市場なども平気で作ります。あるいは, 東洋医学 の薬草，アマゾンの薬草，全部よそさまの世界のも のをコード化してしまって新しい市場を作っていま す。そして，システムを作っているわけです。

こう考えてみますと日本人は，あるいは本日は中 国，韓国の方もいらしていると思いますが，そう いった非常に手先が器用でなおかつ工夫する民族, そういった人たちがアメリカに行って使われて，ア メリカがシステム化していったわけです。はっきり 言って，日本は戦略負けしたのだと思いました。こ れが象徵的に表れているのが医療の世界だと思った わけです。

では，医療の世界はどうしたらいいのか。これは 医療だけに限りません。日本全体の問題です。各省 庁，官庁の政策は，縦割りの “たこつぼ”になって います。エネルギーは経産省, 農林水産業やバイオ マスエネルギーは農水省, サイエンスは文部科学省, 医療は厚生労働省と，全部縦に，“たこつぼ”に分 かれているわけです。アメリカは官庁においても， 政策においても，統合機能があります。われわれは アメリカに負けない，いいものを持っているわけで すから，いかにしてこれに横ぐしを通していくか。 こういう発想で勝算を見い出していくことが重要で す。

もう一つ大事なのは，では，何をターゲットにし てやっていったらいいのかということです。医療の 世界でわたしは思いました。官庁がこんなに縦割り の“たこつぼ”になっているところで，文科省の予 算なのか, あるいは厚生労働省の予算なのか。今か ら申し上げるようないろいろな西洋医学と東洋医学 の融合，あるいは東洋医学で今まで科学的でなかっ た因果関係をデータベース化することを，どちらの 予算でやるのか。どう組み立てると予算が付くの か?みんな今苦しんでいます。

しかし，ちょっと発想を変えますと，今まで医薬 とは関係なかった世界の企業の力を使える。例えば， 世界に冠たる日本のフィルムメーカーは今, デジ夕 ルカメラの時代になって, もう写真フィルムの時代 は終わったと感じている。では何をしょうとしてい るかというと，ライフサイエンスの分野に入ってき ています。後で申し上げますが，医薬の世界でいき ますと, 今, エックス線の画像診断はフィルムに焼
き落としていますが, 今後はその程度のフィルム需 要しかなくなる可能性がある。それで, 彼らが今何 を考えているかというと，ライフサイエンスです。 なぜかというと，フィルムの世界は化学の世界です。 印画紙と活性酸素の関係とか，あるいはイオンを扱 う世界でした。その彼らが今，ライフサイエンスと いう世界に入ってきているわけです。こういったこ れまで医薬とは関係なかったけれども世界に冠たる 技術を持っている産業界と, 先生方のような医療の 臨床ができる現場の人たちが共同歩調を取ることが できれば，わたしはアメリカに対しても十分にリカ バリーショットが打てると思っています。

そういうことで, この後, 皆さん方にわたしが捉 えているところの，なぜ日本は統合医療が進まない のかという弱点, そして, 日本は中国・韓国に比べ て何が得意なのか，これを明らかにして，では具体 的にはどういう作戦やプログラム，プロジェクトで やっていったらいいのかをご紹介したいと思います。 ちょっと前段が長くなりましたが，以下，進めさせ ていただきます。

問題意識は, 縷々申し上げませんが，今後特に大 事なのは, 先生方のように西洋医学と東洋医学を融 合させて，ヘルスケア自体を非常に有効なものにし たいという思いです。

今回の学術総会のテーマの中でも地域における医 療の話がありましたが，ご存じのように厚生労働省 の中位人口推計でも，2100年には日本の総人口は 6000万人程度になると言われています。そうなると， 首都圈周辺の人口が現在の 3000 万人程度とすると, あと残りの3000万人は関西や中京地区，そして中国 地方等に分散して住むことになるわけです。そう なった場合には，今のような過疎化状況はもっと激 しくなり，地域では仕事もどんどんなくなります。 今, 建設業界周辺でも財政赤字のためにどんどん仕 事が減っていて，建設業をやっていた人たちが

「じゃ，おれたちは何をやったらいいんだ」「介護 をやるか？コムスンみたいなものもちょっと変だ な」という状況になっているわけです。だったら，

「農業をやるか？」しかし，どういう形でやって いいか分からない。ただ，地域に住民がいる限り， ヘルスケア・病気予防というニーズがあるわけです から，これと，いわゆる従来型の産業をどううまく 一体型にして地域住民のニーズに応えていくか。そ 
ういう組み立てが必要になると思います。

また中国の食が危ないと，いろいろと新聞に出て います。考えてみますと, 漢方とは何か。私は日経 新聞に書いたおかげで，この世界の方から随分いろ いろとアプローチを受けました。富山の広貫堂とい う日本の和漢薬では最大手の会社からも声を掛けて いただきました。わたしはその富山の広貫堂の方の お話を聞いて，つくづく伝統医療というのは食から 医療を考えるシステムだなと感じました。広貫堂の 社長の話を一言だけ申し上げますと，今日は午後の セッションに富山の国際伝統医学センター長の上馬 場先生もいらっしゃると思いますが，富山の医薬産 業はなぜ発達したか。前田利家の子孫が富山藩の城 主になったときに，産業政策として和漢薬の産業づ くりを行ったのが起源だそうです。400年前です。 そのレシピは中国から入ってきました。熊胆（くま のい）は，800年前の中国のレシピですが，これが どういう経路で入ってきたのかというと, 薩摩と中 国との間の密貿易で入ってきたそうです。なぜその レシピが取れたかというと, 当時の日本には北前船 というのがありまして, 北海道からフコイダンの昆 布の素材が手に入って, それを日本海側から運んで いって，薩摩経由で中国に輸出したわけです。その 代わりに，中国からは熊胆や六神丸がレシピ付きで 入ってきたのです。そのレシピはどんなものだった かと言うと, 800年前, 中国のある地域において非 常に食あたり等が多かったときに熊胆を使ったらこ れが良かったということで，でき上がった体系だそ うです。六神丸も然り，600年前です。そのレシピ が富山に来て，それに基づいて富山は産業として， 北は北海道の昆布, 南は鹿児島の方のサトウキビ等 いろいろなものを組み合わせて和漢薬を作ったそう です。

そこで，漢方には二つ大きな流れがあるというこ とを私は知りました。一つは補法（体温を上げるや り方）で，もう一つは瀉法（デトックス）です。漢 方も究極のところ物理的刺激などいろいろあります が，現在大体西洋医学でもみんなの頭に入っている デトックスと体温を上げること，この二つの流れを 食を通じてやっているシステムだと理解できます。 こういうことを現代風にリアレンジすることによっ て，いかに食を作っていくか。そのときの食とは, 微量ミネラルや酵素などの組み合わせの上に成り
立っているものです。

こう考えていくと，それはIT, コンピューター, 化学会社といった異業種がやっている世界そのもの のわけです。彼らは早晚, 医薬産業に入ってくる方 向にありますので，あとはこれをいかに組み合わせ ていくかとなる。先ほど言いましたようにこう いった分野の特許戦略と先生方，皆さま方がうまく 融合すればよい。アメリカとはまた違った意味で, 必ずしも国などに全部研究費を依存するのではなく， ライフサイエンスをやろうという企業と先生方の知 見がうまく融合すると, 日本は勝てるのではないか と思っているわけです。

以下，やや強弱を付けて説明させていただきます。 ここにご列席のほとんどの皆さまは統合医療をご存 じだと思うので縷々申し上げませんが，今回の東洋 医学会雑誌の巻頭言等を読んでいきますと，すごく 立派な精神が入っていると思います。アメリカでは, 相補 - 代替医療 (CAM : Complementary and Alternative Medicine) と呼んでいます。これは，やはり主 は西洋医学にあるから Complementary and Alternativeになるわけです。しかし，そうではないのでは ないかというのが, Integrative Medicineです。これ はどういうことかというと, 西洋医学と東洋医学を 対等に置いた上での考え方で，より「統合」という 概念に近いと思います。Alternative というのは補完 ですから，これは考え方の根底においてやはり異な るだろうと思います。そういった趣旨のことを，今 回の冒頭の巻頭言にも書いてありました。

そして，ポイントだと思うのがIT 革命のインパ クトです。わたしは日本銀行で経済・金融の専門家 として訓練を経たのですが，富士通総研へ行って良 かったことが一つあります。あそこはご存じのよう に IT 産業で，わたしはシステムの専門家ではあり ませんが，IT 時代になると何が起こるかというこ とが深く理解できました。要は，なぜ統合医療が可 能になったか。一言でいうと，1990年代以降，IT 革命が急速に進んだからです。

具体的に言いましょう。近代西洋医学は科学的で ある，統計学的である，因果関係がしっかりしてい る。だから，Aという事実でもって画像診断をする と, 内藏の情報でも事実がはっきりします。その事 実を形状から見て，がんがここまで進んでいると判 断してきたわけです。一方で，ゲノムの解析もコン 


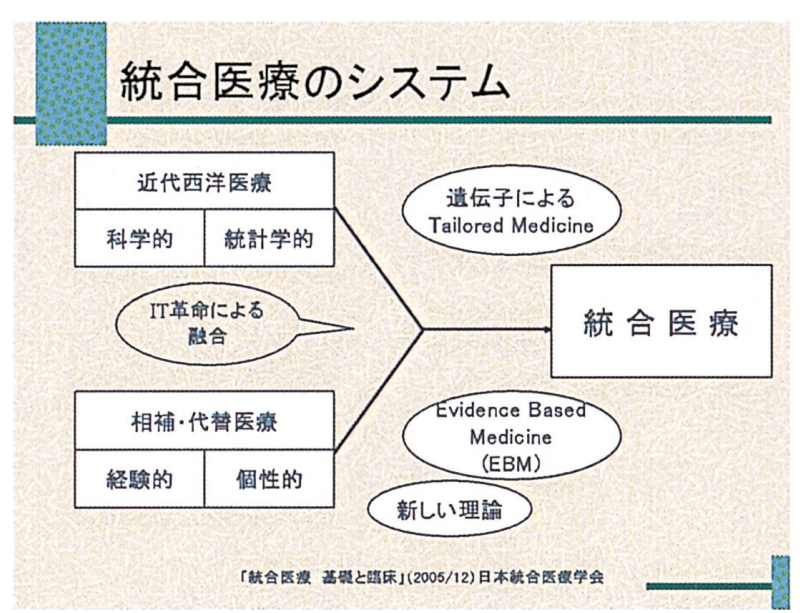

图 1

ピューターで可能になりました。ゲノム解析になる と，遺伝子による tailored medicine が可能になりま す。これが直近の成果です。わたしは今回，こちら へ来る前に，今週号の「News Week」を見てきまし た。読んだ方もいらっしゃるかと思いますが，そこ には，人工合成の生命が誕生するのももう時間の問 題だと書いてありました。なぜかというと，こうい うゲノム解析が可能になっているからです。そうい うことで, 西洋医学の方はどんどん遺伝子を解析す ることによって，一人一人毎に，こういう特質を 持っていたら副作用が出るということが，はっきり

してきているわけです。

一方で, 伝統医療, あるいはこれは東洋医学と読 み替えていいと思いますが，こちらは経験的である， 個性的である，ある人には効くけれども，ある人に は効かなかったりする。あるいは効き目が出て来る までの時間軸が長いですから，因果関係がはっきり しないと言われてきたわけです。

しかしながら，例えば，鍼や炎をやって体温が変 化した場合，体温が上がったことが画像診断で分か るようになっているわけです。あるいは，今次総会 の会頭を務められている十河先生は, 経絡に $\mathrm{N}$ と $\mathrm{S}$ の磁場の変化を与えることによって脈波の変化が 出るという診断方法を完成させていらっしゃいます。 人の脈波の微細な変化の補足についても，先ほど言 いました富士フイルムでは脈波センサーを開発中で す。だから，先生方が持っていらっしゃる名人芸の ところの診断方法が，IT 技術，センサーで可能と なってきます。従いまして，これまでは「あの人は 名人だけれども，他には伝えられないよ」と言って

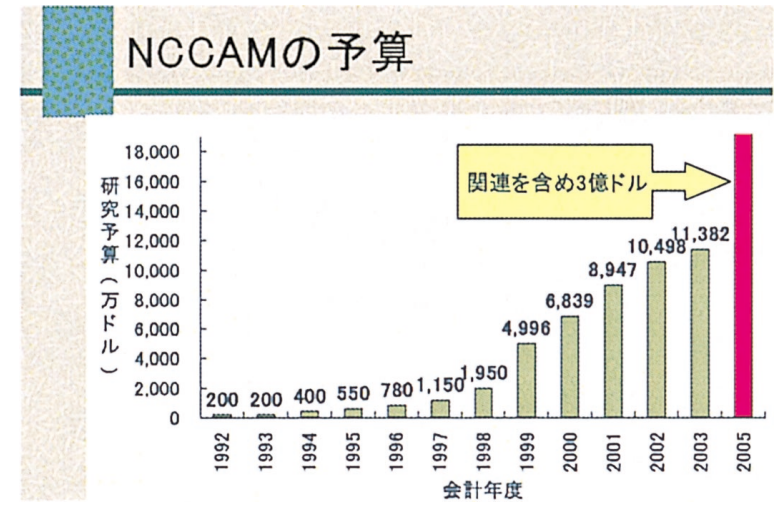

図 2

いた診断方法が，ある程度数值化，デー夕化できる ようになったのです。それが図 1 の下部からの流れ です。

東洋医学も, 今や EBM (Evidence Based Medicine) の時代を迎えているわけです。なぜこんなことが可 能になったかというと，IT 革命の結果です。今後 21世紀に何が変わるのか。さらに IT 革命の影響が 明らかになる。世界ではWeb2.0に向けて動いてい ます。セカンドライフという，現実の世界ではなく， 自分のちょっとあの世の世界における感じのシミュ レーションもできるのがWeb2.0です。今週の 「News Week」をご覧ください。Life2.0と言ってい るのです。Life1.0とは何かというと, 現実の生物 です。それに対して，Life2.0ということが言われ 出したわけです。人工合成する生命がもう生まれつ つある。なぜできるか。IT 鞈です。そういうこ とを考えますと，無理にやろうとしてするのではな い，必然的な結果として統合医療に進むわけです。 そういう潮流でいきますと, 誰が早くこの現実に気 付いて手を打つかだけの話となります。

統合医療の世界の動きは，アメリカでも1990年代 から始まりました。アメリカが代替医療に着目した 理由は，医療費の高騰です。このままだと医療は破 たんするということで，国民が代替医療をどれぐら い使っているのか調べた結果，3 分の 1 は使ってい るとなったわけです。そこで，アメリカのすごいと ころは，国家戦略（ビジョン）を立てたことです。 日本はいろいろなことをやる場合に，国家プロジェ クトでも，どの案件でもプロジェクトとしか言いま せん。プロジェクトというのは，一番下位の概念で す。もう一つアメリカがすごいのは, 戦略の立て方 です。大きな戦略を出すときには，大体アメリカの 
大統領が presidential initiative を出します。大統領指 令というわけです。そして，2020年までにこれこれ のことをしたい，プログラムを立てようというバッ クキャスティングをするのです。2020年のあるべき 姿を想定して，そこから手前まで戻ってくるやり方 (バックキャスティング）でプログラムを立てます。 では，何と何と何をやればいいかというのがプロジ エクトです。それがびしっとシステマティックにで きる。これを90年代からやり始めて，今や特許戦略 を含めて，アメリカは統合医療の具体策が花開いて いるわけです。

ヨーロッパは，アメリカのような医療戦略につい てはやや懐疑的ですが，食品について，中国からの 農薬まみれの野菜を入れないなど，はっきり拒否で きるような違った意味の体系を作っています。ヨー ロッパはどちらかというと食品からのアプローチで すが，アメリカと同じような感覚になっているとお 考えください。

アジアは，21世紀に入って急速に東洋医学会の組 織化等という形でキャッチアップを図ろうとしてい ます。この間，WHOがいよいよこういう統合医療， 東洋医学といったものを正面から見据えて, 特に南 北問題が関係しますので，大車輪での活動を始めた 段階にあります。

アメリカは，CAMを国家的戦略に位置付けまし た。そこが全然違います。NCCAM（National Center for Complementary and Alternative Medicine) という のを作って CAMの分類を行い，パテント戦略の前 提となる漢方薬草のコード化を精力的に推進してい ます。漢方薬の7000種類のコード化が既に完了して います。EUの世界でも食品で進んでいます。予算 の掛け方も違います。アメリカは2005年でこういっ た統合医療，代替医療，東洋医学分野に，トータル で大体 3 億ドル（約350億円）の予算を付けていま す(図 2)。

日本はどうかというと，文科省で数千万円の予算 が付いただけです。そういう状況です。日本はなぜ 後れているか。日本はいい意味でも，悪い意味でも， 健康保険が充実しています。しかも，健康保険が使 えるのは，基本的に西洋医療だけです。いわゆる伝 統医療で使えるのは柔道整復師診療のみで，それを 除いて健康保険の対象になりません。そういうこと で，皆さんの中で東洋医学をなさっている方は，非

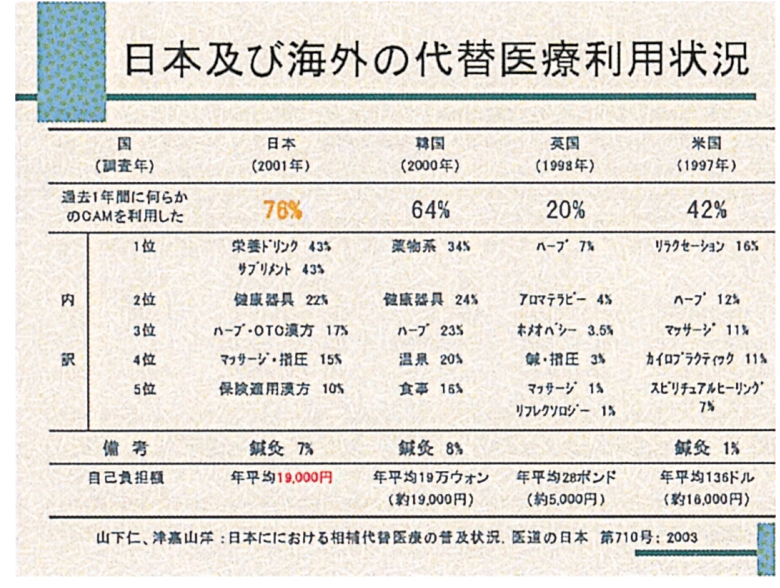

図 3

常にご苦心なさっているのが日本の現状です。医学 教育においては西洋医学のみを教えています。政府 関係機関は世界の医療に対して情報不足で，アメリ カの戦略に気付いていない。こういうことです。

しかし，日本人はいわゆる代替医療，伝統医療， 東洋医学に年間 1 万 9000 円の打金を自己負担で払っ ています。これは韓国並みです。韓国も 1 万9000円 です。イギリスやアメリカに比べても，実際にはこ の分野に扮金を使っているわけです。あとは，政策 や戦略との結び目がないというだけの話なのです

\section{(図 3 )。}

政府や厚生労働省もスタンスをあえて明示してい ないというべきか，ほとんどまだ無関心の状況にあ ります。

政治家はどうか。2005年 3 月に，自公民超党派議 員による「統合医療を推進する議員連盟」ができま したが，残念なことがありました。ここの会長は綿 貫さんです。2005年の夏に小泉劇場がありまして, 綿貫先生はそれで自民党から外れました。そして今， 国民新党のトップということで，キャスティング ボートを握っている，握っていないという話があり ますが，そういう状況になっておりまして，議員の 世界もちょっと統合に集中力を欠いた状況になって います。

学術はどうかというと, 文科省の予算に, 代替医 療の科学的評価方法の開発が計上されていますが, これも数千万円の予算しかありません。

まとめますと, 日本は欧米に比べて東洋医療の利 用率は高いのですが，その研究と教育はともに後れ ています。なぜか。一つには，東洋医学の有効性と 
The Center for Integrated Medicine

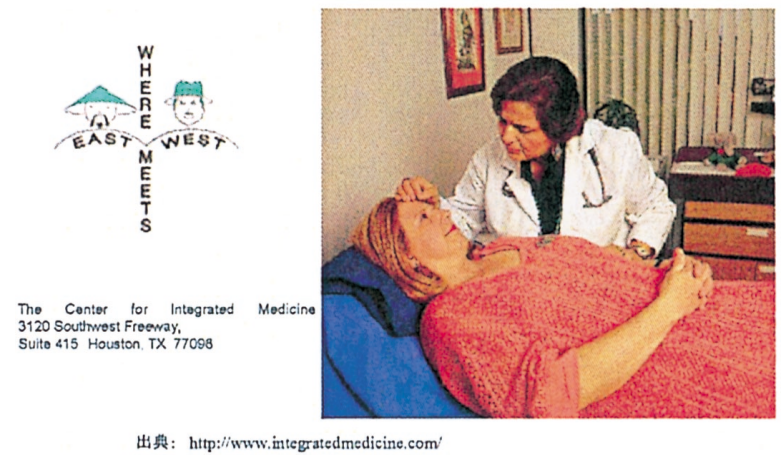

図 4

安全性を公正に評価する公的機関がないからです。 ないということは，こういう機関を何とかして作る べきではないかということです。もう一つは，科学 技術や産業戦略というところでの戦略負けです。し かし，中身はあるわけですから，戦略をいかにして 構築するかだと思います。

時間も限られているので, 科学技術戦略がなぜ重 要かと申し上げますと，こういった分野は，ライフ サイエンスという目でみると，新発見や新しい特許 が成立する宝庫です。今後ヘルスケアやメタボリッ クシンドロームなど，こういう分野からいろいろな 仕事が出てきます。郷土料理など，地域のいろいろ な財産も見直せます。

もちろん哲学がいる，エビデンスがいる。皆さん 全部ご存じだから，これはあえて申し上げません。

アメリカは，これまで述べましたように，はっき りと国家戦略にしています。予算も付けています。

次がアメリカの事例です（図４）。これは，ある 医療センターのホームページに出ているのですが, 病院の中でイーストとウエストがバランス良く, 対 等の立場で医療に当たっているわけです。この先生 は西洋医学の先生みたいですが，鍼みたいなものを 使ってやっています。また学校の中の授業風景です

(図 5 )。完ぺきに対等の，バランスの取れた立場 でやっています。

アジアやアフリカの国は元祖です。漢方, アーユ ルヴェーダ, チベット医学, アラブのユナニとか, そういうものは全部アジア発です。それでやってき たのですが，アメリカの方がどんどん特許で押さえ 始めています。これに対し，アジアの人たちは，「こ れは昔からあるみんな知っている知見だから, 特許
Finger Lakes Community College

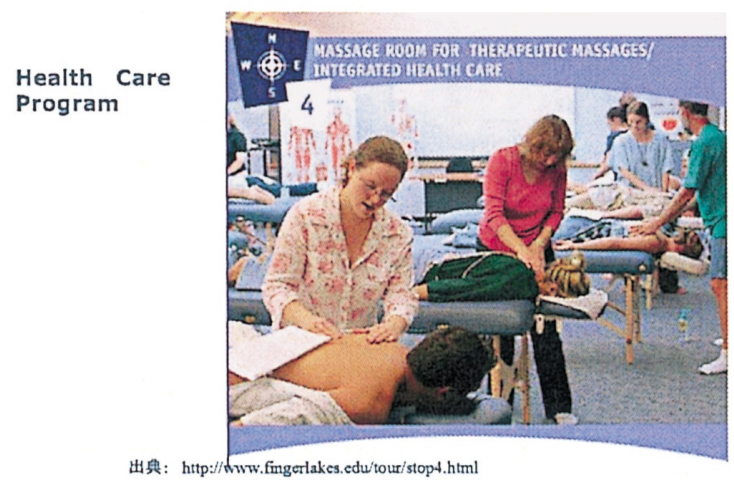

図 5

の対象ではないのではないか」と言っているのです が，今後は綱引きです。言うばかりでは駄目です。 中国, 韓国, 日本が共同戦線を張って，むしろ最初 に特許を取りに行って，そして，特許成立後，逆に 公知化して，一気に開放してしまうとか，そういう 戦略を元祖であるアジアの国はやるべきではないか と思っています。

日本はどうしたらいいのか。既に沖緡の紅麦匊のパ テントが，ヨーロッパの企業によって押さえられま した。こういうことがぽんぽんと出てきつつありま す。

では，日本の強みは何かというと，医工学です。 この分野については, 先ほどの富士フイルムのこと を述べましたが，こういう先を含めて頑張ってもら う。医療器械で最も進んでいるのはアメリカの GE です。なぜ GEがあれだけ医療器械で発達している かご存じですか。一方, 日本トップの東芝が GE に 比べてなぜ弱いのか分かりますか。

GE が強いのは，金融部門を持っているからです。 医療過誤の問題は絶えず発生します。GE は金融(保 険）でそのリスクを分散できるから，これだけがん がんできるわけです。日本の東芝はモノづくりだけ しかやっていません。金融の持っている力，リスク をある程度散らす，保険をする機能がありません。 この世界は総力戦なわけです。

しかし, 日本はパーツからいくと非常にいいもの を持っています。そういうように見ていきますと， あとはこういった装置を使いながら，特許戦略をど んどん進めていくという, 具体論をやればいいので はないかということです。

日本にも, 内閣府に総合科学技術会議というのが 


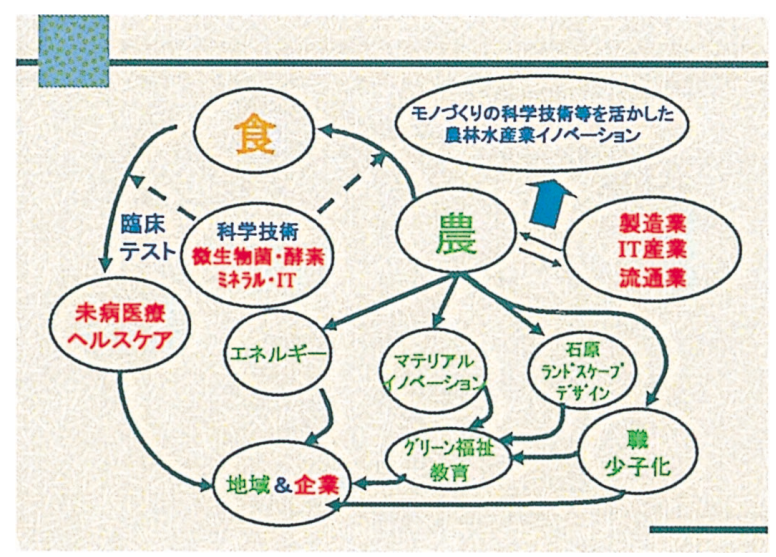

図 6

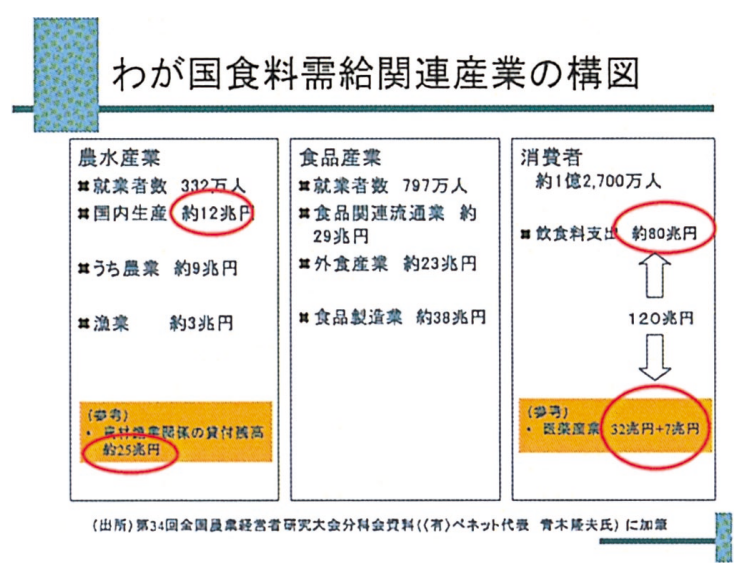

図 7

あり，知財戦略，特許戦略を推進しましょうと言っ ていますが，残念ながら，これといったキラーコン テンツがありません。「やろう，やろう」と言って いますが，総花的に並べてあります。特に統合医療 を進めましょうというようなセンスはありません。

また内閣府には，IT 戦略本部というのがありま す。森元首相のときに始まり，「アイテー」と言っ てちょっと失笑を買った「IT」という言葉なのです が，現在は，第 2 次 5 か年計画に入っています。私 は，今からの統合医療というのは IT 戦略そのもの だとう形で位置付けて，むしろ IT 戦略の中核の 概念にしたらどうかと思っています。それともう一 つは，アメリカの NCCAM 類似の, CAM の分類で す。日本でもいろいろな薬草があります。日本山人 参など，いいものがいっぱいあります。こういうも のの標準化，あるいはそれのデータベース化を，公 的な組織としてやるべきだと思います。

釈迦に説法ですが，やはり伝統医療，東洋医学と いうのは精神の安定性等々，すべて全体的に考える わけですから，歴史の浅いアメリカにはない奈良の お寺など，日本は芸能文化資源の宝庫と言えます。 残念ながら，文化庁にはこういった日本に点在する あらゆる文化のデータベースがまだありません。こ ういうデータベースをむしろ統合医療資源として再 構築する，こういった戦略を，日本は取るべきでは ないかと思います。お寺のお香などもアロマセラ ピーになっているわけですから。

そして，アジアではどう考えたらいいか。文科省 は，アジア科学技術協力の戦略的推進ということを 揭げていますが，何をしていいか分かっていません。 本日は，中国，韓国の方々がいらっしゃるようでし

たら，ぜひ黒船になっていただければありがたいと 思います。日本としてもこの統合医療，東洋医学の 戦略化，あるいは国際標準化をぜひ一緒になって やっていきたいと思っているわけですが，日本の場 合は海外から声が掛かると非常に世の中が動きやす い。もし中国，韓国の先生方がお聞きでしたら，ぜ ひ中国，韓国サイドから「日本よ，やろうではない か」という形で，日本にとっての黒船になっていた だきたい。そうすると日本は動きます。外圧に弱い 国，日本でございますので，ぜひよろしくお願いし たい。

次に，そこのコンテンツを何にするか。統合医療 のアジアの科学技術戦略ですが，例えばチベット医 学に象徴されますように, 東洋医学は宗教と医療と 文化の三位一体で成り立っています。そういうこと を考えますと, 日本のお寺の元祖のルーツなどを含 めて，文化資源を再構築，データベース化すること は，東アジア，あるいはアジア共通の戦略目標にな るのではないかと思います。

産業政策については, 日本の場合は, 医薬産業以 外にも診断メーカー，あるいはあらゆるモノづくり メーカーがあります。総力を挙げて，ターゲットさ えはっきりさせれば，非常に有効ではないかと思い ます。

そして，今後日本の取るべき戦略として考えられ ますのは，先生方は未病医療やへルスケアを扱って いらっしゃいますが，一方で，今は農業が崩壊状態 にあります。食料自給率は穀物で 2 割, カロリーベー スでは 4 割で， 6 割を輸入しています。その中に恐 ろしい中国の食品も交じっています。日本も集めら れたものではありませんで，ポジティブリストとい 


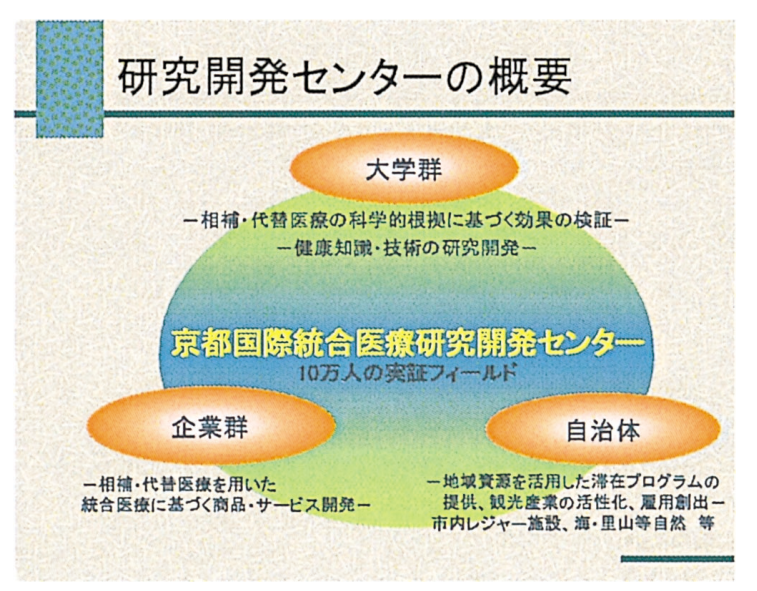

図 8

う，使っていい農薬リストが去年ようやくできたば かりです。いずれにせよ重要なことは, 農業にして も, 食にしても, 科学技術がベースになって微生物 菌や酵素やミネラルを, 同じ意味で, 同じ尺度で評 価できるようにすることです。同じ尺度で評価でき たら，これらを束ねることができます。束ねたら産 業になります。そして, 農業の下にエネルギーがあっ て, 皆さんご存じのバイオマスエネルギーなど, こ ういうことが全部つながります。つまり，ある地域 内でぐるっと回って, いろいろな産業が成り立つ世 界になります。日本が強いのは製造業のモノづくり のセンスだし,またIT 産業, 流通業も結構強いの です。従って，こういうモノづくりと先生方のよう なライフサイエンスとが一体になっていくことで, これこそ日本の力を発揮できるのではないかと思う わけです（図６）。

ちょっと大きな話だけ先にします。先ほどアメリ カの医療産業は1.6兆ドルと述べましたが, 日本は ご存じのように医療の世界は32兆円, 薬品が 7 兆円 で約40兆円です。一方で飲料食品の世界は80兆円で す。日本で生産している食の生産は, 農業で 9 兆円, 漁業は半分輸入しているので1.5兆円。国内生産 10 兆円に輸入で, 消費段階では80兆円の規模に化けて いるわけです。食医統合で, 食と医を一体的に考え なくてはいけません。ここの120兆円の市場, 生 産 の段階, 農業の段階から食品加工, 先生方のライフ サイエンスのセンスを合わせていって，120兆円も ある大きな市場を再構築することで, 必ず日本は勝 てると思います。そういう形によって, 今日の東洋 医学会参加の先生方にも, 夜明けは近いという意味 で申し上げているわけです（図７）。

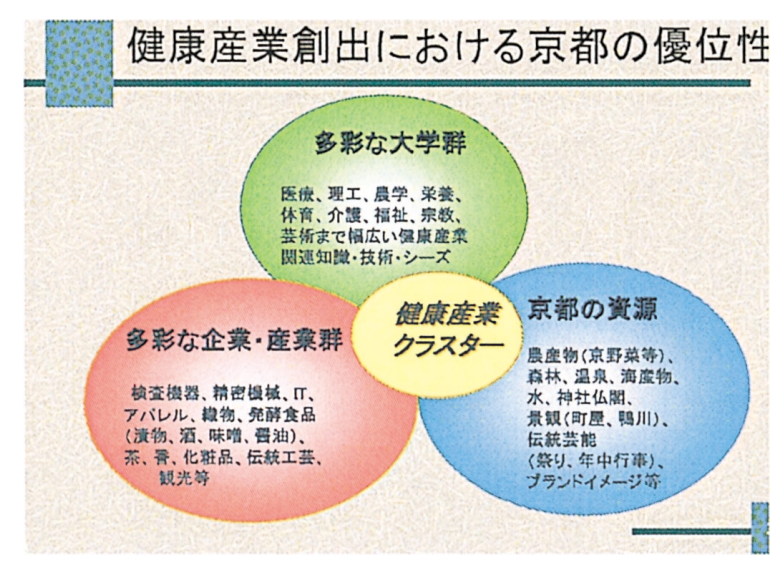

図 9

具体的にどうするかというと，やはり地域で医療 を中心に，あるいは食を作るところを中心に，地域 の産業を再構築したらどうか。その際には, 東洋医 学のセンスを持った先生方に大きな中心の役割を果 たしていただきたいということです。

具体的には京都でやろうとしていますが, ご存じ のように, 京都市は京都大学, 府の方は京都府医大 と, 中でいろいろなせめぎ合いがあるようで今まだ スタートしておりませんが, アイデアは出ていまし て, 健康産業クラスターと呼ばれています。こうな りますと医学が発酵技術など, みそやしょうゆなど の世界と合うわけです。そして, 京都には神社仏閣 がありますから，非常にいいという発想になるわけ です。アメリカにはこんなものはありません。わた しの縁のある長崎でもこういうことは可能です。西 洋医学が入った長崎では, そのほかにドロ神父さん が産業を伝えて，医学も伝えました。こういうのを 地域に立ち上げたらどうかと思います（図８，図 9 )。

そして, 日本がもう一つ優れているのは, 西洋医 学分野で放射線医学研究です。重粒子がん治療のセ ンターというのは日本にしかありません。これは千 葉にあります。加速装置で最も重い重粒子をピンポ イントでがんの患部に当てますと, 穴が開いても平 気な臓器の場合は, 30分 2 回通うだけで, 320万円 だったでしょうか，それで健康保険が適用されてい ます。これには世界が注目しています。こういうも のがあるわけで，こういった西洋医学と東洋医学の 知見をつなげると，いろいろなクラスターが考えら れる(図10)。

農業と食と医療をかませる。こうしたことになる 
と，例えば金持ちの中近東の連中は，チャーターし た飛行機ごとやってきます。東洋医学や代替医療が 良いのは，リピートせざるを得ないところです。絶 えず日本に来て，しばらくの間滞在しなければなり ません。そういうことになりますと，皆さんも決し て日本の中だけで怙客さん（患者）を考えるだけで なく，金持ちを中近東から引っ張ってくる。そのと き，日本は八百万の神の宗教ですから，イスラムを 決して排除しません。アメリカが病院を輸出するの だったら，日本は向こうから客を引っ張ってくると いう発想でやればいい。そうすれば産業としても成 り立つし，国内だけで健康保険の収支をバランスさ せようというのは非常に限界がありますが，少し新 しいフィールドが見えてくるのではないかと思いま す。

ここで政策課題をお話ししたい。やはり科学技術 政策と医療政策の統合です。これは先生方もいろい ろとお考えでしょうが，なかなか実現していません。 昨年のことですが，4月27日の新聞記事を見た福井 県健康福祉部の責任者がわたしに「福井でもやりた い。福井もいろいろな東洋医療資源を持っているけ れども，どうしたらいいのだろう」と相談がありま した。議論をしていろいろ分かりました。例えば福 井にある薬草がいいという評価を県が出そうとする 場合，これは厚生労働省との調整が必要になってき ます。そういうことを考えますと，国全体の政策が そういう方向に変わらない限り, 県単位ではなかな か難しいというのが見えて来ました。

従って，国家としては軍でも統合参謀本部という のがあるように，各省庁の統合機能が必要となる。 陸軍，海軍，空軍，これを統合するのがアメリカの 強みです。日本ももうそろそろこういった縦割り “たこつぼ”の政策をやめたらどうかということで す。そのときに一番いいのは統合医療です。これは 産業政策でもあり，医療でもあり，文科省の政策で もあります。これをむしろ戦略のターゲットにすれ ばどうだろうかということです。

こう言うと，これもないものねだりで，「政府が 動かないからだめだ」と言って悲観的になりがちな のですが，最後に今産業界に起こっている夜明けが 近い話をして，締めくくりにしたいと思います。

実はわたしの家内も大腸がんをやりまして，西洋 医学の先生に執刀してもらい, その後, 免疫療法も

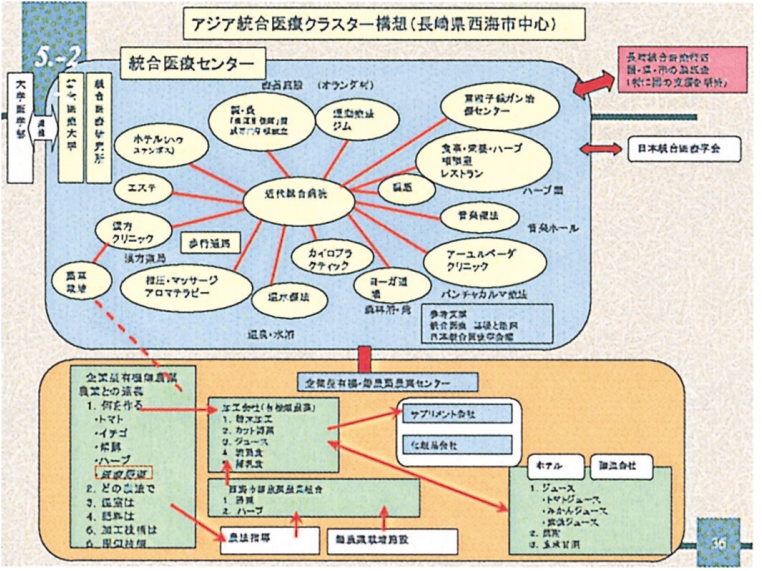

図10

やりながら，日本の医療体制内で起こっていること の現状を，家族の問題として随分知りました。そし て，今次総会への打誘いを契機に，会頭の十河先生 と知り合うことができました。十河先生が何をな さっているかということは後で拈話があると思いま すが，経絡現象学です。具体的には，経絡診断検査 と経絡貼薬治療という二つの構図になっています。 先生はその体系を完成なさって，近々に本が出ると いう段階になっています。

そこで，わたしは先生と，「これは中国5000年の 知見を先生が現代風にリアレンジし，西洋医学的な 観点から解釈を加えて開発された体系なので，僕の センスからいくと，これが出てしまうとアメリカで 特許取得，そしてアメリカにまた押さえられてしま うおそれがありますね」といった議論を始めました。

アメリカでは，治療法は特許として成り立ちます。 皆さんもご存じの Oーリングテストというのがあり ます。大村先生という方がアメリカで $\mathrm{O}$ ーリングテ スト法という特許を成立させています。こんなと 言っては悪いですが，Oーリングテストが特許に なっているのです。そこで，わたしも大車輪で調べ ました。日本の場合は，治療法は特許になりません。 しかしながら，先ほどの脈波センサーなどを組み合 わせたトータルシステムであれば，日本でも特許に なり得ます。それでいろいろ調査しましたが，その 過程で，名前を言いますが，富士フイルムのライフ サイエンスをやっている化学の専門家から，あの業 界が医薬の世界をどう見ているのかということを， すごく感動の思いで私は聞きました。

今の日本の医薬産業界はシステム障害を起こして いるそうです。西洋医療の病院に行って，がんを 
切っても治らない。そして，抗がん剤をぼんぼん入 れて，もちろん抗がん剂もどんどん新しいのが出て いることも知っていますが，それで治療しても免疫 力を下げてしまうというように二律背反を起こして いる。彼らは次のように予感しています。この10年 内に今の医療体制は崩壊してレガシーになる。なぜ か。医薬の産業はパラダイムが変わっている。どう いうことかというと，わたしが今回お話しした

$\lceil$ News Week」と同じょうに, 電子や分子, 量子レ ベルで生命を科学できる企業や人が続々と登場して いるからです。そして，日本人というのは分析の緻 密化にこだわる。わたしも研究者ですから，よく批 判を受けます。わたしの研究内容は, 構想にすぐい くわけです。なぜかというと, 分析をいくらやって 先に延ばしても，何も生まれないからです。

日本の場合は，これまで演繹や帰納というやり方 が科学的な手法といわれていましたが, 皆さん, 今 申し上げる「アブダクション (abduction)」という 言葉を覚えてください。これは演繹や帰納とは違う, 第 3 の推論形式です。ある意味で直感, ひらめきで す。ワープするわけです。こういう手法が出ていま す。それで成功しているのが, 例の DNA でノーべ ル賞を取ったワトソンさんとクリックさん。彼等は このやり方だといわれています。これと同じことが， 創薬の世界でも起こっているそうです。そういう意 味では，アブダクションできる人はいるのですが， それをなかなか企業で抱える状況にはなかったよう です。しかしながら，こういった人がどんどん前面 に出つつある。IT 革命で膨大なデー夕処理が可能 となったことも影響しているようです。

また，現在の医療経済は破たんすることになる。 厚生労働省は, 今32兆円の医療費用が, このままで いくと何年か後には50兆円だ，60兆円だと，無責任 なことを言っています。一方，少子高齢化とともに， 医療保険制度を支える若い人たちの数がどんどん 減って，破たんすることは分かっているわけです。 破たんしたら何が起こるか。破たんは怖くありませ ん。破たんしたらまたゼロからの出発です。既得権 を持っていた人が全部崩れます。社会保険庁みたい なものです。そうなりますと，これまでのことはな しにしょうということにならざるを得ない。一番イ ノベーションが起こるのは破たんしたときです。今 まで歴史的に最もイノベーションが起こったのはい
つかというと, 戦後です。戦争をすれば全部消える。 そして, 新しいものが起こる。2 番目には, 異業種 の参入が容易化します。今までは医薬のところは限 られた世界で，他の者ががたがたいう筋合いではな いと言っていましたが, 先ほどの話のように, 鹿島 といったゼネコンのような異業種でもライフサイエ ンス部門を持っています。そういう参入者がどんど ん増えたら，はっきり変わります。

終わりに, 先生方に私から期待を述べたいと思い ます。異業種がどんどん参入する事態になった場合， 先生方は何が強みなのか。臨床という現場を持つ医 師の役割がますます重要化するわけです。だから， ライフサイエンス産業や農業, 食産業, IT 産業が いくら頑張っても, 先生方のように生命を扱える臨 床という立場でないと，これは完成しません。従い まして, 東洋医学会は新しい視点で, 先生方はそう いう立場にあられるわけですから, 産業界が求めて いるパートナーとして, ぜひお力をいただければと いうことになろうかと思います。

そして，もう一つ，すぐに日本では予算が欲しい となる，データベースの予算が欲しいと文科省に言 うことになるのですが，例えばビル・ゲイッなど， アフリカのエイズのために私財をなげうつような人 がぽんぽんと出てきています。日本の企業は金を 持っています。金を持っているのに何に使っていい か分からないのです。そういうことを考えますと， 企業もぜひ先生方と一緒に特許を取っていくという 戦略を推進していくべきではないかと思います。し かも，IT 革命でデー夕処理が容易になっています。

そして, 中国, 韓国両国から招越しの先生方には ちょっと失礼かと思いますが, 中国, 韓国に比べて 日本の東洋医学会の強みが一つあります。それは何 かというと, 中国に抒いても韓国においても, 西洋 医学と中医, 韓医というものが対立して, 独立の立 場を持っています。この点, 韓国に扔いては, 今, 韓医の方が西洋医学よりももうかるといわれていま す。なぜかというと, 韓医の人たちが科学技術者と 一緒になって科学化しているからで, その代わり再 者の対立は非常に激しいものになっているそうです。

日本はそうではありません。西洋医学の先生方が, 今日も十河先生をはじめ東洋医学の分野の知見にす ごく理解を示され，アプローチとしては西洋医学的 な方法で東洋医学を再構築して, なおかつ西洋医学 
でしかできない外科や緊急外来などとはうまく協力 して，そして日々の生活改善を含めたところできち んと両者が融合していくという考え方を取っていま す。相手を全面否定するのではなく，相手の良さを 取り込んで組み合わせる。こういう発想で進んでい らっしゃるのは，まさに日本の有利な点だと思いま す。

本日は後ほど中国，韓国の先生方の報告もあろう かと思いますが，こういう日本の持っている強みを 十二分に生かして，そして政府に頼らなくとも，企 業との間の連携を先生方が図っていく。東洋医学会 がそういうことをやれば，21世紀になってあらゆる パラダイム，基本的な考え方は変わっていますが， 違った形でアメリカと十分に伍していけるような国 に日本はなれると思います。私は医療の専門家では ありませんので，今日は経済や産業，あるいはイノ
ベーションということで，先生方にどのような協力 をしていただければ日本が勝てるかという話をした つもりでございます。

今後 2 日間にわたる会議で，わたしがプレゼンさ せていただきましたような問題意識も含めて，少し 大きな観点からより議論が進化することを期待いた します。ご清聴ありがとうございました。

石川 先生, 非常に示唆に富んだご講演をありが とうございました。特にシステムやマーケットイノ ベーションに関しては非常に後れていますし，実際 にシナリオプランニング技法など用いて危機管理を する必要があると思います。やはりこれからの東洋 医学会がそういうべースを持ちながら，どういう形 で異業種と手を結んでいくかということは，非常に 重要なことだと思います。本当にありがとうござい ました。 